mediators in HIV-related pneumonia; different role of IL2 and IL1 in inducing lung damage. Chest 1993;103:439-44.

45 Schrier RD, McCutchan JA, Venable JC, Nelson JA, Wiley CA. T-cellinduced expression of human immunodeficiency virus in macrophages. f Virol 1990;64:3280-5.

46 Merrill JE, Koyanagi Y, Chen ISY. Interleukin-1 and tumor necrosis factor $\alpha$ can be induced from mononuclear phagocytes by human immunodeficiency virus type 1 binding to the CD4 receptor. $f$ Virol 1989;63:4404-8.

47 Molina J-M, Scadden DT, Byrn R, Dinarello CA, Groopman JE. Production of tumor necrosis factor $\alpha$ and interleukin $1 \beta$ by monocytic cells infected with human immunodeficiency virus. $\mathcal{f}$ Clin Invest 1989; 84:733-8.
48 Clouse KA, Cosentino LM, Weih KA, Pyle SW, Robinns PB, Hochstein $\mathrm{HD}$, et al. The HIV-1 gp120 envelope protein has the intrinsic capacity to stimulate monokine secretion. F Immunol 1991;147:2892-6.

49 Furuta T, Ueda K, Fujiwara K, Yamanouchi K. Cellular and humoral immune responses of mice subclinically infected with Pneumocystis carinii. Infect Immunol 1985;47:544-8.

50 Harman AG, Stankiewicz M. Requirement for CD4 + cells in resistance to Pneumocystis carinii pneumonia in mice. 7 Exp Med 1990;172:937-45.

51 Pesanti EL. Interaction of cytokines and alveolar cells with Pneumocystis carinii in vitro. $\mathcal{F}$ Infect Dis 1991;163:611-6.

52 Mann DL, Gartner S, Le Sane F, Buchow H, Popovic M. HIV-1 transmission and function of virus-infected monocytes/macrophages. f Immunol 1990;144:2152-8.

\title{
Adventitia
}

\section{Woods and trees}

"Are you the obsessional type?" asked the interviewer. "Do you lie awake worrying about upside down quotation marks?" "Oh no!" I laughed. The hoped for answer to this half serious question, however, was "yes"; but happily I got the job. The interviewer was Dr Joan Faulkner, wife of Sir Richard Doll, and the job was in the publications section of the Medical Research Council's headquarters. Thirty three years later I can say that anyone who is deeply obsessional would find much to lose sleep over and had better not do an editorial job: perfection may be unrealistic, and anyway it is often better to see the wood than every branch of every tree.

At the MRC "the wood" was for many years absorbing and often immensely exciting. At Oxford I had read Classics and philosophy and then I had briefly taught Latin and Greek; so to learn something of molecular biology, cytogenetics, and radiobiology, for example, seemed a great privilege-especially in the 1960s, when these were key growing points of research. A labour intensive but seductive part of the work was to make the scientific articles in the council's annual report to parliament more reader friendly for MPs and other "intelligent laymen"; but probably few laymen read these articles, at least those fascinating and intricate ones (on, for example, bacterial sexuality) on which I lavished such loving care. So eventually they gave way to shorter pieces on recent developments.

In $1977 \mathrm{I}$ joined the $B M \mathcal{H}$, where I wrote articles and was correspondence editor as well as subediting and sometimes rewriting papers. The editor, Stephen Lock, who taught me so much, coined the word "glogging" (verb "to glog") for the radical editing he wanted me to do. I loved my work with the $B M \mathcal{F}$ but in 1982, after getting married, I wanted a part time job and was lucky to be able to move to Thorax. Here I enjoyed working with successive editors and their assistants, the many authors with whom I had contact, and my friends at the printers, Eyre and Spottiswoode. Deadlines imparted a certain drama to the work and I became a familiar but finally unwelcome figure at the late post sorting office to which, if necessary, I walked or jogged or, as a last resort, drove.

The BMF style book, which Thorax largely follows, provided a court of appeal-especially useful for editorial changes made mainly for consistency, like putting a comma before "and" ("red, white, and blue"), to take a small example. But all through my career it irritated me if someone said patronisingly, "You look after the grammar and the commas and things, don't you?"-partly because I did much more than this, but also because these may be a route to both clarity and logic, and even to a critical analysis of the writing, providing tools for sorting out muddles. The use of the subjunctive, as in "If I were editor," illustrates usage that is rooted in logic but also in convention, its use being much more sparing in English than in some other languages. More interesting and important are the cases where logic holds a less disputable sway, as in the misuse of commas to separate the inseparable, as Fowler puts itcommon in complex sentences, especially between subject and predicate: "The pressure you experience by wanting to reach a certain goal .... in a limited time, is called time pressure." Similarly, the presence and absence of commas with descriptive and defining words and clauses are not a matter of taste, for they depend on what job the word(s) or clause is doing in the sentence: compare "The editor, who deals with editorials" with "The editor who deals with editorials." Of course I could go on and on, with examples of increasing complexity; but the Editor wouldn't like it.

Language, however, is dynamic and flexibility must have a place, though I took exception to the opening of a Sunday Times article of long ago: it claimed that a particular phrase had become correct thanks to British Rail.

DAPHNE GLOAG

(Technical Editor of Thorax from 1982 to 1993)

This column is now open to allcomers for suitable contributions (maximum 600 words). We would like to keep this column running. SGS 